\title{
THE APPLICATION OF "AIDA” MODEL TO ECONOMIC CLASSES
}

\author{
Liu Chaojie, liuwillam@163.com \\ Zhejiang Ocean University, Zhoushan, Republic of China
}

\begin{abstract}
China's college expansion plan since 1999 has gradually diverted its higher education from the elite education to popular education. Millions of students have chances to receive higher education, thus, meeting the public demands for the higher education, which not only helps to improve the overall quality of the human resources and the population cultivation, but pushes the economic growth to enhance the comprehensive national strength as well. However, the quality of the present higher education couldn't reach the requirements of both economic and social development. Besides, the university expansion enrollment has brought about a series of defects that have been witnessed by the occurrence of economy crises in 2008. It is difficult for college graduates, especially those with major in Economics, to find a job after the economic crises in 2008. This paper attempts to discuss the application of AIDA method to the economic classes on the basis of analysis of the status quo of economic classes so that the role of the teacher in class can be redefined, so as to foster the students' abilities to analyze and solve practical problems.
\end{abstract}

Keywords: economic curriculum, AIDA model, application-oriented talents cultivation.

The outline of "national middle-term and long-term education reform and developing plan" for 2010-2020 put forward that the essences of the educational development rely on reform. The reform focuses on the educational system and organism. Henceforth, it is important to encourage the local government and universities to make innovations and reform education content, methods, assessment systems [1]. Today the competition is growing and economic education as the main part of higher education is playing an important role in pushing the society to move forward and change the knowledge model. The developing tendency of economy is good and the students' enrollment is increasing. However, there are some problems in the education of students whose major is Economics. The goal of students' cultivation is not distinct, students cultivation model adheres to the past, and teaching content is obsolete. Henceforth, with the task of training students with good practical skills, the essay introduces the application of AIDA method to the economic classes based on the analysis of the status quo of economic classes, so that the role of the teacher in class can be redefined to foster the students' abilities to analyze and solve practical problems.

\section{Main problems in economic classes}

To teach is to learn, which reveals that teaching is an art with the combination of teaching and learning. In addition, it gives mutual benefits and interactive performances. However, in today's university class, the situation is the opposite one. The teacher always acts as the leader and the students obey. The teacher usually focuses on his teaching rather than the students' learning, ignoring the demands of the students and the society. The main problems in economic classes are the following ones.

\subsection{Curriculum design \\ is not reasonable}

Professor Bai Yongxiu admits that in the post-reform era, interest-related parties differentiate the relationships between human beings, between the human being and the society, and the groups between groups bringing about the change, conflicts and unbalance of values assessment. The education focus is on the shortterm achievement, rather than the long-term cultivation [2]. Curriculum design, which includes the teaching content design and the optimization of teaching structures is the key factor of improving the teaching qualification. At present, the economic curriculum in many universities is not reasonable. In western economic curriculum, for example, the studying hours are 2 hours per week (some university have 4 hours per week), and the total number of studying hours is 32 every term. The task of teaching couldn't be completed due to limited teaching hours, henceforth, in the classroom they could only slash the teaching content or focus some points. There is not enough time for teachers to analyze their economic principles in depth as the time limit for every class is 


\section{Теория и методика профессионального образования}

50 minutes. This fact decreases the students' desire for further learning.

\subsection{Teaching method is unitary}

At present, almost all the teachers carry out their teaching performance with the help of multi-media. During the teaching process, most of the teachers deeply rely on their PPT presentations and some teachers just ask students to watch the "PPT" without explanations. Their PPT mainly consists of teaching materials, basic economic principles and formulas, rather than the model analysis and daily application. Henceforth, when the teacher delivers his class with enthusiasm, the students feel dull even sleepy. If the situation lasts for a long time, the students will absorb nothing in the class. Such one-way communication mode makes students passive listeners, not active learners.

With one-way communication mode in economic class is difficult to motivate students to study and to cultivate the students' linguistic abilities, critical thinking skills, learning abilities and invocation abilities, not to mention enhancing their organization and coordination abilities and teamwork abilities.

\subsection{Lack of practical experience}

University teachers are rich in theories but are lack of practical experience due to long-term teaching in class. Henceforth, they focus on theories rather than practices in classes, and ignore the connections between different subjects. Many universities treat the practical education or the professional training as internship, excluded from the university curriculum system, ignoring the importance of practical education. At Chinese Universities, the student qualification assessment (by means of score ) usually consists of two parts, one is their daily performance (class participation and homework) in classes which usually take 30 or $40 \%$ of the assessment and the other is the final examination test concerning basic theories and formulas which usually take 70 or $60 \%$ of the assessment. Such kind of qualification assessment is adverse to cultivate students' learning skills and application abilities. The FEANI puts forward the world famous "FEANI formula" $\mathrm{B}=3 \mathrm{U}+2(\mathrm{U} / \mathrm{T} / \mathrm{E}+2 \mathrm{E}) . \mathrm{B}$ represents time spent to cultivate a qualified engineer, $U$ represents a semester of a university project, $\mathrm{T}$ means one year of professional project training, E represents one year of engineering related working experiences, $U / T / E$ mean that any of them could be altered in certain circumstances [3]"FEANI formula" reveals that it takes at least 7 years to cul- tivate a qualified engineer and it also reveals a qualified engineer must have the experience of engineering projects practice and engineering related working experience (which exceeds the total studying hours in university). From the "FEANI formula", we could also deduce that the professional practice education is vital in economic classes at Chinese universities. Without plenty of professional training practice, the skills and theories, what they have learnt could not meet the demands of the society, especially, for students from the economic field.

\section{Introduction of "AIDA" model in economic class}

In economic classes, some teachers usually focus on the knowledge delivery, rather than the interest and emotion motivation. Henceforth, the voice of reform of economic classes could be heard loudly. In order to speed up the reform, the writer thinks that it is necessary to introduce "AIDA" model in economic classes.

\subsection{The definition of "AIDA"}

"AIDA" is the abbreviation of four words. "A" is "Attention", attracting somebody; "I" is "Interest", make somebody interested in something or somebody; " $D$ " is "Desire", motivate somebody to do something; the last letter " $A$ " is "Action", taking action. "AIDA" formula is a very famous marketing principle and it was put forward by a world famous marketing experts Heinz M Goldman from his personal marketing experience. The specific explanation is that a successful salesperson must try his best to attract his consumers to focus on their products, make his consumers be interested in his products, henceforth, the consumer will desire to purchase the product and then the final action is the deal. "AIDA" formula represents the four developing processes of marketing and they are closely bonded. "AIDA" formula reveals an effective information transferring regulation: attract attention, arouse interest, motivate desire, act.

\subsection{The probability of introducing} "AIDA" in economic classes

To some extent, education is a kind of activity. In the activity, the educator following the teaching objectives selects suitable information and transmits the knowledge, skills, ideology and concepts to the learners. In the teaching activity, transmitting information to the learner is not an easy task. As for the learners, to receive information from their teachers is not equal to accept the information. Receiving is different from accepting, because receiving is a passive activity but ac- 
cepting is an active activity [4]. Transmitting information to students could also be seen as a marketing process. In such kind of marketing process, what the teacher sells is knowledge, while his students are his consumers. How could the teachers sell their products perfectly, how could they attract their consumers are the questions that the teachers should solve. As for the teachers, knowledge is necessary but it is not enough. In such kind of marketing process, the teachers should be proficient at using marketing skills, such as communication skills, the ability to examine a man's language and observe his countenance, the ability to analyze learner's needs, likes. "AIDA" formula is a successful marketing principle and has great impact on marketing activities. Actually, the teacher could also draw lessons from the formula.

\section{The inspirations of "AIDA" \\ to the economic classes \\ in Chinese universities}

Benjamin Franklin said that "Tell me and I will forget, teach me and I will remember, involve me and I will learn." Henceforth, attracting the students' attention, motivating their desires, encouraging students to participate in the classes and vigorously get absorbed in the teamwork are the tasks for the teachers.

\subsection{Attract the students' attention}

Gaius Julius. Caesar has ever said: "Veni! Vidi! Vici! (I have come, I have seen and I have conquered!). When the teacher sets foot into the class, he should attract the students by means of eye contact and conquer them. In the post-reform era, the students are younger generations. Most of them were born after 1990s, when the science and technology were developing rapidly and their living conditions were transformed greatly. Living in a comfortable environment, those students prefer to relax or pursue their personal interest, rather than concentrate on their study. The obstacle for the teacher is to draw the students' attention.

How can a teacher draw students' attention?

Firstly, the teacher should carefully prepare and design their lessons before class. Before class the teachers could communicate with students by means of short messages, e-mail, "QQ", "webchat" and other social media, which could help the teachers to know learners' habits, attitudes, knowledge and the existing problems in their study. Secondly, the teachers should teach students in accordance with their aptitude and, consequently, adjust his teaching content according to the students' performances. Thirdly, the teacher should perfectly control his class and make achievement in the 45 minutes class, which requires the teaching materials to be reasonable, distinct and the teaching methods innovative and acceptable [5].

Last, the teacher should constantly communicate with the students, especially, keep eye contract. Eye is the window to the soul and it is also the magic weapon of attracting the students' attention. When the students automatically communicate with their teachers by eye contact, they send a positive signal to the teacher. Motivation is the inner factor to drive. If the students have clear studying target, the motivation is becoming stronger and stronger.

\subsection{Arouse the students' interest}

Psychologists think that the basis of interest is a need and interest is closely connected with emotions and recognition. If there is no recognition at something or activity, there will be no emotions, not to mention interest. On the contrary, the more you are devoted, the stronger the emotions are and the interest is growing. Interest is the best teacher. Generally speaking, most of us would like to pay more attention to something that interests us, because we could get satisfaction from the process. Students' interests are obliterated in classless and the gap between the teachers and the students is big. If a teacher wants to improve his teaching qualifications objectively, he should cultivate and arouse the students' interest. Richard Vee Law pointed out that teachers could cultivate and arouse the students interest by the following 6 means: concise and vivid teaching materials, raise questions at the right time, walking around the class, the application of visual aids to object teaching, the application of electronic teaching equipment and the arts of linguistic humors. The author thinks that it is not realistic for the teachers to take all of the means, while they should chose some of the means according to their reality. The author holds on that, walking around the class, applying the arts of linguistic humor make classes more colorful. From some perspectives, teacher is a multirole person (director, designer, actor and audience) in class.

\subsection{Motivate the students' learning desire}

The desire of human being is the distinct reflection of human nature. American psychologist has divided human being's desire into five hierarchical levels: basic needs, security needs, need recognition, need in self-esteem, and need in selfactualization. The learning desire is that if the 


\section{Теория и методика профессионального образования}

students are motivated by the knowledge in class, the desire of learning is growing. When people's basic needs and needs in security are satisfied, they would like to reach a higher level of mental pursuit. And the desire to learn belongs to the mental pursuit. There is only one millionth' difference between interest and desire. If the teacher could convert the students' interest into desire, the teaching objects will learn with half effort. Most of the time, the interests come into students' mind immediately, however, it is difficult to come into the following desire. Henceforth, the teachers must consolidate the students' desire of learning knowledge.

\subsection{Encourage the students \\ to take actions}

The key difference between "want" and "get" is whether you have taken action or not. Action is the most important part in the whole process. Even if the teachers have attracted the attention, aroused students' interest, converted interest into desire, it will also fall short of success for lack of the final action. Bai Yongxiu, Ren Baoping, Wu Zhenlei put forward that the mission of education in post-reform era is to cultivate expert or scholar type talents, entrepreneur type talents and social organization type talents and their cultivation standards are as following (tables 1-3) [6].

The teacher should help students to know which fields they are more qualified and talented and which fields they want to engage in their further career plan. As long as students solve the problems above, they could take actions.

\section{Based on "AIDA" formula, a new role of university teachers in economic fields}

"The qualification of universities is not defined by tall building but by its teachers. Henceforth, excellent teachers are the basic resource that a university could mainly depend on". Excellent teachers are the spring of university, because they could not only stimulate students to study but could also make friends with their students. Then, how should the teachers reconsider their role? Liu Man divided the teachers' role into three types: the first is the education-oriented type. Such type of teachers take education as

The training standard of expert and scholar type talents

Table 1

\begin{tabular}{|l|l|}
\hline Academic morals & $\begin{array}{l}\text { Moral, justice, love, passion, social responsibility, entrepreneurial spirits, highly profes- } \\
\text { sional dedication }\end{array}$ \\
\hline Knowledge structure & $\begin{array}{l}\text { Professional economic knowledge, mathematics and other science, philosophy, history, } \\
\text { literature, economic and society }\end{array}$ \\
\hline Academic ability & Ability of observation, ability of analysis, innovative ability, ability of expression \\
\hline Innovative thinking & $\begin{array}{l}\text { Formation of new concept, establishment of new theory, } \\
\text { the idea of new proposal, new decision making, new technology invention }\end{array}$ \\
\hline
\end{tabular}

The training standard of Entrepreneur type talents

Table 2

\begin{tabular}{|l|l|}
\hline $\begin{array}{l}\text { Advance } \\
\text { Concept }\end{array}$ & $\begin{array}{l}\text { Have a good command of the natural concept of market economy be familiar } \\
\text { with the concept the general market economy, have a good command of modern economy }\end{array}$ \\
\hline $\begin{array}{l}\text { Qualified } \\
\text { Characteristics }\end{array}$ & Theory qualification professional qualifications, mental heath, physical health \\
\hline Entrepreneurship & $\begin{array}{l}\text { The spirit of entrepreneurship and innovation, the spirit of professionalism and spirit } \\
\text { of dedication }\end{array}$ \\
\hline $\begin{array}{l}\text { The capacity } \\
\text { of management }\end{array}$ & $\begin{array}{l}\text { The ability of management and decision-making, the ability of development and innova- } \\
\text { tion, the ability of marketing analysis, the ability of finance analysis, the ability of high } \\
\text { working efficiency }\end{array}$ \\
\hline
\end{tabular}

The training standard of social organization leader type talents

Table 3

\begin{tabular}{|l|l|}
\hline Moral Standard & Solidarity and cooperation ,broad-minded toward others, modest and prudent \\
\hline Knowledge structure & Political position, political viewpoints, political qualifications \\
\hline Level of expertise & Professional knowledge and business skills of economics \\
\hline Humanities & The correct world outlook and scientific methodology \\
\hline Mental qualification & Faithful, determined, perseverance, optimistic \\
\hline
\end{tabular}


their main task and their legitimate foundation and manly concentrate on students' growth and development. Traditionally, the teachers are not only teachers but they embody educators, engineers of souls, the gardener, the representative of knowledge, the authority, and moral incarnation. The second is a knowledge-oriented type. Such type of teachers takes recognition as their legitimate foundation and mainly focus on academic research of disciplines and professions. The third type is a politics-oriented type. Such types of teachers take politic functions as their legitimate foundation and highly stress the learners' social readabilities, national services, and contributions. As the society develops, the role of contemporary teachers acquire new meanings and they are considered to be the mouthpiece of the society, and representatives of social moral. The university has become a place for high-tech incubator and knowledge promotion [7]. Combined with the above viewpoints, we think that "AIDA" model provides us with a significant and analytic tool. Under the guide of "AIDA" model, the teachers should reconsider their roles in the following four aspects.

\subsection{Teachers are the leaders of students' self-study}

The ancient Chinese philosophy goes like that "where there is a student, there must be a teacher and the teacher is to solve all the doubts of a student». Using the "AIDA" model standard, the education should be learner-centered. The teachers should guide students to know the outlook of the world and facilitate learning. "Plato is dear to me, but dearer still is truth", henceforth, the teachers should not force students to follow their viewpoints. The teachers should coach and lead students to build a platform for knowledge construction and transmission rather than knowledge impart.

\subsection{Teachers are the class designers}

Class design is the main task of teachers. "Give me a fulcrum, and I shall move the world". Class design could create fulcrums for all the students, which could help them to find their ways of learning and open the door of knowledge. In the process of class design, the teacher has the right of autonomy, so that they could balance the ratio between theories and practices. Firstly, using advanced modern education equipment, the teachers could build up a new curriculum system which could not only improve the old-fashioned curriculum system but also pro- mote the all round developments of students. Secondly, the teachers could design the practical curriculum in accordance with the students and society needs.

\subsection{The teachers guide students to future life}

"Great learning makes a teacher; moral integrity makes a model" which reveals that the teachers should follow all the regulations and laws and set examples to their students but they should not be restricted by the regulations and moral models. The teachers should usually reconsider their behavior and accept the students' appreciation with critical thinking, encourage individuality and the spirit of creativity and enable students to think about their country and their people. In addition, the teacher should care about their students' happiness, sadness, angers to establish a beautiful class world, where the virtue could be rooted, grow up and speed to the whole society, which could make contributions to the social development.

\subsection{Teachers are the dedicators \\ in the society}

The formal President of Beijing University Mr. Xu Zhihong said that in China, there is no university which ranks the first-class in the world. He pointed out that there are three standards for world-famous university: firstly, there are world famous professors who are engaged in the world advanced researches; secondly, there are no such kinds of achievements that they have obtained have pushed the movement of civilizations and the rapid development of the world economy and world peace; thirdly they haven't cultivate students, that have made great contributions to the development of China [8]. Every country consists of numerous individuals, every individual should make his efforts to push the society move forward. Teachers, as the dedicators in the society, should help students to establish their social responsibilities and awareness of consciousness of national master, which is also the final target of education.

\section{The Conclusion}

As a new methodology in teaching, the "AIDA" model should be examined in practice. "AIDA" model is not a panacea, but it is beneficial for teachers. "AIDA" is an attempt of new teaching models. As long as we make full use of the model, the teachers and the students both will benefit a lot from it. 


\title{
References
}

1. National Plan for Medium and Long-term Education Reform and Development (2010-2020). Available at: http://www.gov.cn/jrzg/2010-07/29/content_1667143.htm (accessed 22.06.2015).

2. Bai Y. [A Review and Prospect of China's Economics Education Mark the 60th Anniversary of the Founding of the PRC]. Economist, 2009, no. 7. (in Chin.)

3. Sun K. [Discussion on the Problems and Countermeasures of Engineering Education and Practice and it's Attribute of General Education]. China University Teaching, 2011, no. 9. (in Chin.)

4. Li D., Sun X., Zhou J. [The Teaching Strategy Analyses of Economic and Management Classes Based on AIDA Model]. Higher Agricultural Education, 2010, no. 6. (in Chin.)

5. Jia Z. [Simple Analyses of AIDA Model Pedagogy]. Commercial College of Guizhou, 1988, no. 3. (in Chin.)

6. Bai Y., Ren B., Wu Z. [Base on the Two Fulcrums the Original and Methodology to Tampe the Basis of Economic Talents Cultivation]. China University Teaching, 2011, no. 9. (in Chin.)

7. Liu M. [The Role of College Teachers]. Journal of Technology College Education, 2007, no. 5. (in Chin.)

8. Xu Z. China Has no Global Top-ranking Universities. Available at: http://news.163.com/10/ 0415/01/649A3M490001124J.html (accessed 22.06.2015).

Received 17 August 2015

DOI: $10.14529 /$ ped1504011

УДК 378.014.54

ББК Ч448.026

\section{ПРИМЕНЕНИЕ МОДЕЛИ АІDА В ОБУЧЕНИИ СТУДЕНТОВ, ЗАНИМАЮЩИХСЯ В КЛАССАХ ЭКОНОМИЧЕСКОЙ НАПРАВЛЕННОСТИ}

\author{
Лю Чаоцзе \\ Шжэцзянский Океанический университета, г. Чжоушань, \\ Китайская Народная Республика
}

\begin{abstract}
План увеличения количества колледжей, реализуемый с 1999 года, внес существенное разнообразие в систему образования и превратил образование из элитного в доступное. У миллионов студентов появился шанс получить высшее образование, что в свою очередь, помогло удовлетворить спрос на высшее образование, которое способствует не только повышению качества человеческих ресурсов и культурного уровня жителей страны, но и экономическому развитию страны и увеличению ее национального дохода. Однако качество высшего образования на сегодняшний день не соответствует требованиям социального и экономического развития. Кроме того, увеличение количества студентов привело к экономическому кризису 2008 года. Выпускникам вузов экономического направления довольно трудно было найти работу в 2008 году. В статье описывается применение метода обучения AIDA (модель развития способности решать практические задачи) для студентов, специализирующихся в экономике. Проведенное исследование основывается на том, что роль преподавателя в классах экономической направленности должна быть пересмотрена, то есть основная функция преподавателя - развитие способности студентов анализировать и решать практические задачи.
\end{abstract}


Ключевые слова: учебный план студентов экономический специильностей, модель AIDA, модель развития способности решать практические задачи.

Лю Чаоцзе, секретарь международного отдела, Шжэцзянский Океанический университета, г. Чжоушань, Китайская Народная Республика; liuwillam@163.com.

Поступила в редакцию 17 августа 2015 г.

\section{ОБРАЗЕЦ ЦИТИРОВАНИЯ}

Liu Chaojie. The application of "AIDA" model to economic classes / Liu Chaojie // Вестник ЮУрГУ. Серия «Образование. Педагогические науки». - 2015. - Т. 7, № 4. - C. 77-83. DOI: 10.14529/ped150411

\section{FOR CITATION}

Liu Chaojie. The Application of "AIDA" Model to Economic Classes. Bulletin of the South Ural State University. Ser. Education. Educational Sciences. 2015, vol. 7, no. 4, pp. 77-83. DOI: 10.14529/ped150411 